\title{
Physiochemical characteristic of Harvested Rain water from Bodo Community in Rivers State, Nigeria
}

\author{
${ }^{1}$ IKHIOYA PE; *OSU CHARLES I.; OBUZOR, GU ${ }^{3}$ \\ "Department of Pure and Industrial Chemistry, University of Port Harcourt, P.M.B 5323 Choba, Port Harcourt, Rivers State, Nigeria., \\ Telephone: +234803 7783246 email: charsike@yahoo.com
}

\begin{abstract}
This study was carried out to determine the quality of rainwater from three different roofing materials (asbestos, aluminum and zinc) in Bodo Community of Rivers State, Nigeria. Samples were taken to the laboratory and analyzed using standard analytical procedures. The average result obtained ranged from $6.0-7.0,40-66 \mu \mathrm{si} / \mathrm{cm}, 18-48 \mathrm{mg} / 1,32.52-86.67 \mathrm{mg} / \mathrm{L}$, $0.06-3.18 \mathrm{mg} / \mathrm{L}, 5.02-13.76 \mathrm{mg} / \mathrm{L}, 2.79-5.02 \mathrm{mg} / \mathrm{L}, 0.16-0.77 \mathrm{mg} / \mathrm{L}, 0.27-5.79 \mathrm{mg} / \mathrm{L}, 0.24-0.62$ $\mathrm{mg} / \mathrm{L}$ and $0.03-4.08 \mathrm{mg} / \mathrm{L}$ for $\mathrm{pH}$, conductivity, chloride, salinity, nitrate, sulphate, sodium, magnesium, calcium, iron and zinc respectively. Of interest were rainwater samples from asbestos roofing sheets which gave high calcium and magnesium content. Also, zinc roofing sheet gave high zinc and iron content compared to other roofing sheets. Physico-chemical properties and metal content of the harvested water from the roofing sheets were considerably different from those of control samples (water collected directly from raindrop). This could mean that the impinging of rain drop on the roof gradually erodes the roof material or could be as a result of anthropogenic inputs (deposits of pollutants in contact with roofing sheet) or geographical location. Considering the result of the analysis the harvested water could be put to other domestic use, as they can not be consumed directly. ( $\mathrm{JASEM}$
\end{abstract}

http://dx.doi.org/10.4314/jasem.v19i4.15

KEYWORDS: rainwater, roof materials, water quality

\section{Introduction}

The issue of rainwater harvesting is now a widely used technique for the provision and supply of both portable and non-portable supply of water especially in developing Worlds where the potable water are insufficient to meet the growing needs of the society due to rapid industrialization and development as well as population growth (Olaoye and Olaniyan, 2012). In many areas of the world today, it can either be the only source of water for the household or more commonly a supplementary supply to ease the burden of water collection from other sources (Vikaskumar et al., 2007). Of all the rainwater harvesting methods, the rainwater runoff from household roofs is the most common form of rainwater harvesting. Apart from being cost effective and the ease of maintenance for effective long term system operation, the roof top runoff also has less contamination of rainwater runoff as compared with ground catchment system. Furthermore, roof catchment provides water supply at the point of consumption (Gould and Nissen-Peterson, 1999). The harvest is relevant in areas having significant rainfall but lacking conventional water supply system. The effective roof area and material used in construction influence the efficiency of collection, water quality and quantity. Despite having some clear advantages over other sources, rainwater use has frequently been rejected on the ground of its limited capacity or due to water quality concerns. This is unfortunate as in many cases some simple upgrading and the integrated use of rainwater collection with other technologies is all that is required to obtain a cost effective and reliable water supply solution (Ragab et al., 2003). Roofs provide an ideal catchment surface for harvesting rainwater, provided they

are clean. However, Chang et al., 2004 reported that roofs can be a serious source of nonpoint source pol lution as well. Contamination by chemical pollutants may arise from a variety of materials with whichthe rainwater comes into contact; starting from $t$ he atmosphere. Rainwater could dissolve gases and $\mathrm{w}$ ash off chemicals from contacting dust particles and $\mathrm{r}$ oof materials (Quek and Forster, 1993). Several studie s have looked at the effect of roofing material on harvested rainwater quality but common roofing materials and coating will vary across the country and the world (Olaoye and Olaniyan, 2012). It therefore becomes important to assess the quality of rainwater from different roof material within the case study area.

This paper investigates the physical and chemical properties of rainwater harvested from different types of roofing sheets. 


\section{MATERIALS AND METHODS}

Study Area: Bodo is an Ogoni community located in Gokana Local Government Area of Rivers State. It has an estimated population of 69,000 people. It is located at an elevation of 399 meters above sea level. It is made up of 35 villages. The vast community is Ogoni but other ethnic groups are represented including Ibibio, Igbo and Hausa. This study area was chosen because of non-availability of public or private water mains in the area, the major source of water for domestic use are from rain, hand dug well and borehole. Unfortunately, the majority of the wells dry up during the dry season when the rain ceases while the borehole water is sold. The community relies extensively on available rainwater because it is cheap and accessible in the raining season.

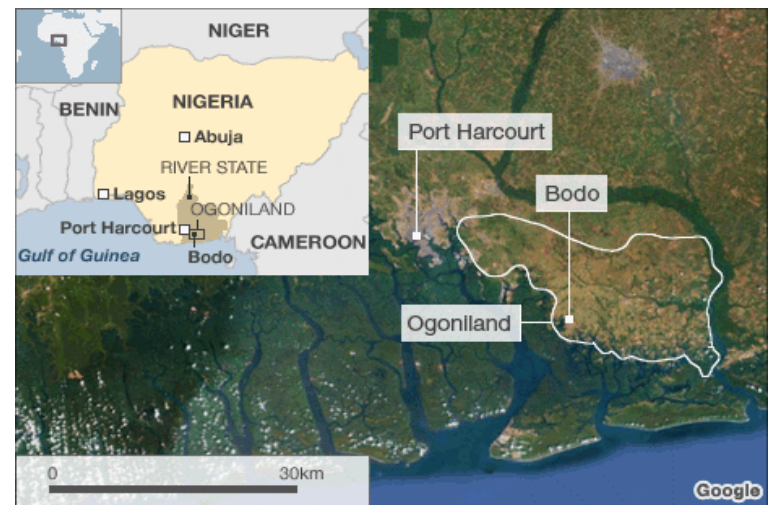

Fig. 1: Map showing the position of Bodo
Sampling and Experimentation A random sampling technique was employed in selecting the sampled household. Harvested rainwater samples were collected via roof-top run off. Three selected roofing sheet materials were analyzed for physico-chemical and metal content using standard method for the examination of water. The roofing materials include asbestos (A), Aluminum (B), Zinc(C) and control samples (D) which was collected directly without contact with any roofing material. Water samples were collected in the months of May (at the onset of rainfall), July (the first peak of rainfall) and September (the rising period of rainfall after the August break). Care was taken to ensure that samples were representative of water to be examined and that no accidental contamination occurred during sampling. Sample containers were rinsed with distilled water and drained before they were used to collect the rainwater sample from the different roofing types. The collected samples were taken to the laboratory for immediate $\mathrm{pH}$ determination. All $\mathrm{pH}$ measurements were made at laboratory temperature. Samples and control were treated in triplicate and analysis was carried out following standard method s (APHA, 1998). Concentration of metals ( $\mathrm{Na}, \mathrm{Mg}$, $\mathrm{Ca}, \mathrm{Fe}, \mathrm{Pb}$ and $\mathrm{Zn}$ ) were determined using Buck scientific atomic absorption spectrophotometer (AAS), GBC Avanta 2.02. Samples for metal determination were first subjected to digestion and aspirated using the appropriate lamps for the metals.

\section{RESULT AND DISCUSSION}

Table 1: Physicochemical and metal analysis of harvested roof top water sample

\begin{tabular}{|c|c|c|c|c|c|c|c|c|c|c|c|c|}
\hline Sample & $\mathbf{p H}$ & $\begin{array}{l}\mathrm{EC} \\
(\mu \mathrm{si} / \mathrm{cm})\end{array}$ & $\begin{array}{l}\mathrm{Cl}^{-} \\
(\mathrm{mg} / \mathrm{l})\end{array}$ & $\begin{array}{l}\text { Salinity } \\
(\mathrm{mg} / \mathrm{l})\end{array}$ & $\begin{array}{l}\mathrm{NO}_{3}{ }^{2-} \\
(\mathrm{mg} / \mathrm{l})\end{array}$ & $\begin{array}{l}\mathrm{SO}_{4}{ }^{2-} \\
(\mathrm{mg} / \mathrm{l})\end{array}$ & $\begin{array}{l}\mathrm{Na} \\
(\mathrm{mg} / \mathrm{l})\end{array}$ & $\begin{array}{l}\text { Mg } \\
(\mathrm{mg} / \mathrm{l})\end{array}$ & $\begin{array}{l}\mathrm{Ca} \\
(\mathrm{mg} / \mathrm{l})\end{array}$ & $\begin{array}{l}\text { Fe } \\
(\mathrm{mg} / \mathrm{l})\end{array}$ & $\begin{array}{l}\mathbf{P b} \\
(\mathrm{mg} / \mathrm{l})\end{array}$ & $\begin{array}{l}\mathrm{Zn} \\
(\mathrm{mg} / \mathrm{l})\end{array}$ \\
\hline$\overline{A 1}$ & 6.0 & 63 & 45 & 81.26 & 2.71 & 13.76 & 3.31 & 0.77 & 5.79 & Nil & Nil & 1.02 \\
\hline B1 & 6.6 & 46 & 30 & 54.18 & 0.19 & 10.32 & 3.90 & 0.49 & 1.08 & Nil & Nil & 0.16 \\
\hline C1 & 6.2 & 47 & 38 & 68.62 & 1.28 & 12.38 & 4.84 & 0.54 & 2.82 & 0.37 & Nil & 3.55 \\
\hline D1 & 6.7 & 42 & 21 & 37.94 & 0.09 & 6.33 & 3.01 & 0.23 & 0.81 & Nil & Nil & 0.03 \\
\hline A2 & 6.2 & 66 & 42 & 75.84 & 2.44 & 11.23 & 3.15 & 0.50 & 4.26 & Nil & Nil & 1.06 \\
\hline B2 & 6.8 & 48 & 29 & 52.38 & 0.16 & 8.46 & 3.04 & 0.31 & 1.12 & Nil & Nil & 0.11 \\
\hline $\mathrm{C} 2$ & 6.4 & 52 & 35 & 63.21 & 1.15 & 10.81 & 3.94 & 0.45 & 2.04 & 0.24 & Nil & 3.39 \\
\hline D2 & 7.0 & 40 & 18 & 32.52 & 0.06 & 5.02 & 2.79 & 0.16 & 0.27 & Nil & Nil & 0.01 \\
\hline A3 & 6.0 & 57 & 48 & 86.67 & 3.18 & 12.43 & 3.41 & 0.73 & 5.33 & Nil & Nil & 1.23 \\
\hline B3 & 6.6 & 45 & 34 & 61.40 & 1.12 & 10.34 & 3.12 & 0.41 & 1.28 & Nil & Nil & 1.04 \\
\hline C3 & 6.4 & 50 & 40 & 72.23 & 1.56 & 11.32 & 5.01 & 0.63 & 3.01 & 0.62 & Nil & 4.08 \\
\hline D3 & 6.8 & 40 & 25 & 45.16 & 0.12 & 7.22 & 2.91 & 0.20 & 0.60 & Nil & Nil & 0.05 \\
\hline $\begin{array}{l}\text { WHO } \\
\text { LIMIT }\end{array}$ & $6.5-8.5$ & 900 & 250 & 500 & 50 & 250 & 200 & 20 & 75 & 0.3 & 0.01 & 5 \\
\hline
\end{tabular}

The average $\mathrm{pH}$ of rainwater samples collected from the different roof types ranged from 6.0-6.2, 6.6-6.8 and 6.2-6.4 for asbestos, aluminum and zinc roofs respectively while control ranged from 6.7-7.0 as shown in Figure 2. The $\mathrm{pH}$ values of most samples analyzed were below the WHO allowable limit for portable water (6.5-8.5) except water samples from aluminum roofing sheet that fell within WHO allowable limit. The $\mathrm{pH}$ values obtained in this study agreed with the result of Yaziz et al., (1989) and Simmons et al., (2001) with reported pH of 5.2 to 11.4 for harvested rainwater. 


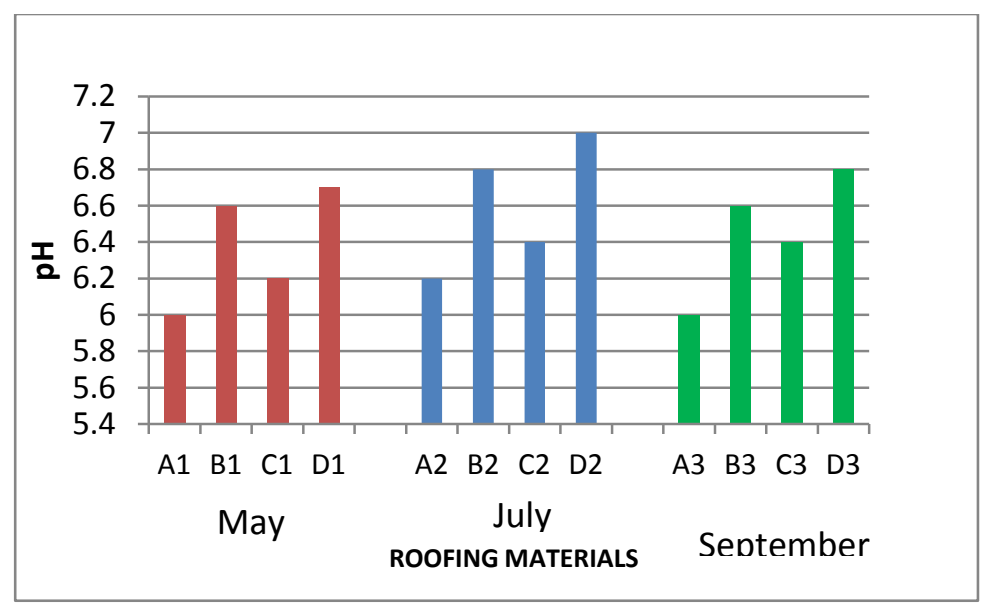

Fig2: $p H$ concentration of rainwater harvested from different roofing materials $\mathrm{A}=$ Asbestos, $\mathrm{B}=$ Aluminum, $\mathrm{C}=$ Zinc, $\mathrm{D}=$ Control

The conductivity values obtained ranged from 57-66 $\mu \mathrm{si} / \mathrm{cm}, 45-48 \mu \mathrm{si} / \mathrm{cm}, 47-52 \mu \mathrm{si} / \mathrm{cm}$ for asbestos, aluminum and zinc respectively while control ranged from $40-42 \mu \mathrm{si} / \mathrm{cm}$. This is in accordance with Mendez et al., (2010) that reported a range from 18 to $61 \mu \mathrm{si} / \mathrm{cm}$. It was observed that conductivity was highest in the water collected from rooftop with asbestos roofing sheet irrespective of the period of collection as shown in Figure 3. This was followed by zinc roofing sheet and then aluminum roofing sheet. However, all the values were less than $900 \mu \mathrm{si} / \mathrm{cm}$ which is the WHO drinking water quality standard.

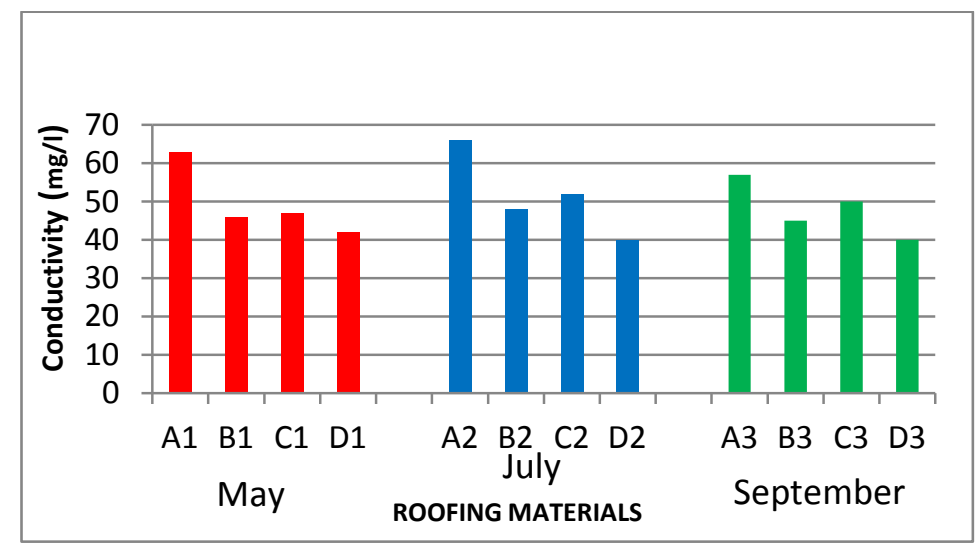

Fig 3: Conductivity concentration of rainwater harvested from different roofing materials $\mathrm{A}=$ Asbestos, $\mathrm{B}=$ Aluminum, $\mathrm{C}=$ Zinc, $\mathrm{D}=$ Control

The average salinity values ranged from 75.84-86.67 $\mathrm{mg} / \mathrm{l}, \quad 52.38-61.40 \mathrm{mg} / \mathrm{l}, \quad 63.21-72.23 \mathrm{mg} / \mathrm{l}$ for asbestos, aluminum and zinc roofing sheets respectively while control ranged from 32.52-45.16 $\mathrm{mg} / \mathrm{l}$. It was observed from Figure 4 that salinity was highest in water samples obtained from asbestos roofing sheet irrespective of the period of collection. However, all the values were less than the WHO maximum allowable limit for drinking water standard $(500 \mathrm{mg} / \mathrm{l})$. 


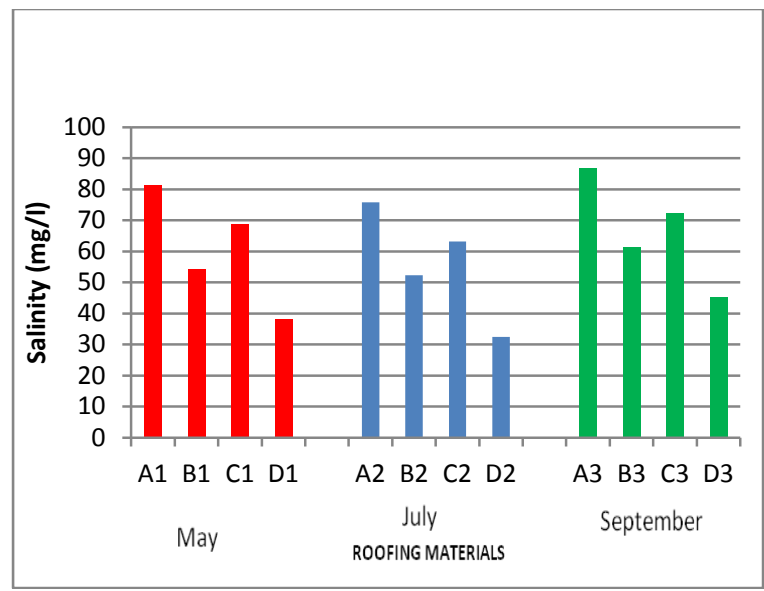

Fig 4: Salinity concentration of rainwater harvested from different roofing materials $\mathrm{A}=$ Asbestos, $\mathrm{B}=$ Aluminum, $\mathrm{C}=\mathrm{Zinc}, \mathrm{D}=$ Control

Figure 5 shows chloride concentrations from the different roofing materials. The chloride concentration in all analyzed samples ranged from $42-48 \mathrm{mg} / \mathrm{l}, 29-$ $34 \mathrm{mg} / \mathrm{l}, 35-40 \mathrm{mg} / \mathrm{l}$ and $18-25 \mathrm{mg} / \mathrm{l}$ for asbestos, aluminum, zinc and control respectively. The chloride values agreed with Eruola et al., (2010) that ranged from 20 to $35 \mathrm{mg} / 1$.

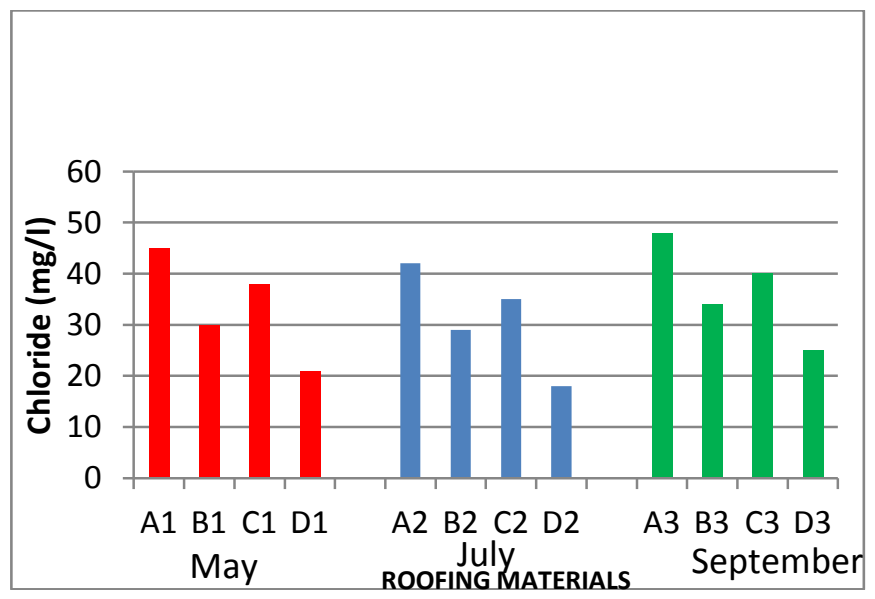

Fig 5: Chloride concentration of rainwater harvested from different roofing materials $\mathrm{A}=$ Asbestos, $\mathrm{B}=$ Aluminum, $\mathrm{C}=$ Zinc, $\mathrm{D}=$ Control

Nitrate values obtained from all the water samples analyzed fell below the WHO standard $(50 \mathrm{mg} / \mathrm{l})$, ranging from 2.44-3.18 $\mathrm{mg} / \mathrm{l}$ for asbestos roofing sheet, $0.16-1.12 \mathrm{mg} / \mathrm{l}$ for aluminum roofing sheet, $1.15-1.56 \mathrm{mg} / \mathrm{l}$ for zinc and $0.06-0.12 \mathrm{mg} / \mathrm{l}$ for water collected directly from raindrop (Figure 6). Sulphate values obtained ranged from 11.23-13.76 mg/l for asbestos roofing sheet, 8.46-10.34 mg/l for aluminum roofing sheet and 10.81-12.38 $\mathrm{mg} / \mathrm{l}$ for zinc roofing sheet while control ranged from 5.02-7.22 mg/l. The WHO limit for sulphate is $250 \mathrm{mg} / \mathrm{l}$ 


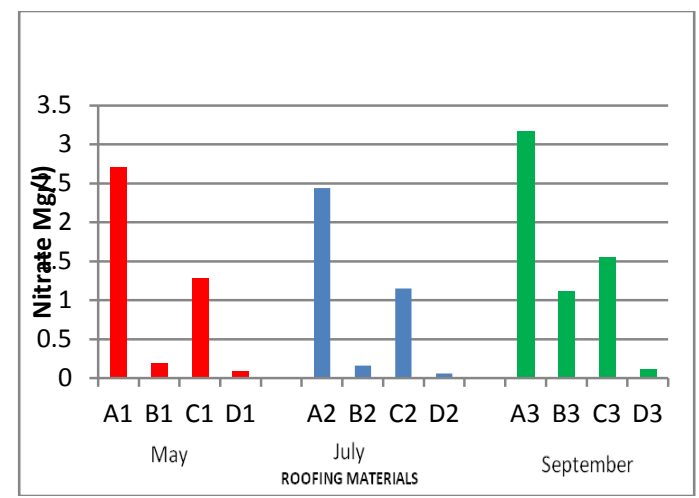

Fig 6: Nitrate concentration of rainwater harvested from different roofing materials $\mathrm{A}=$ Asbestos, $\mathrm{B}=$ Aluminum, $\mathrm{C}=$ Zinc, $\mathrm{D}=$ Control

Figures 8 and Figure 9 shows calcium and magnesium concentration of the different roofing materials during the various rainfall periods in the study area. The calcium values ranged from $4.26-5.79 \mathrm{mg} / \mathrm{l}, 1.08-1.28$ $\mathrm{mg} / \mathrm{l}, 2.04-3.01 \mathrm{mg} / \mathrm{l}$ and $0.27-0.81 \mathrm{mg} / \mathrm{l}$ for asbestos, aluminum, zinc roofs and control samples respectively. The magnesium values ranged from $0.50-0.77 \mathrm{mg} / \mathrm{l}, 0.31-0.49 \mathrm{mg} / \mathrm{l}, 0.45-0.63 \mathrm{mg} / \mathrm{l}$ and $0.16-0.23 \mathrm{mg} / \mathrm{l}$ for asbestos, aluminum, zinc roofs and

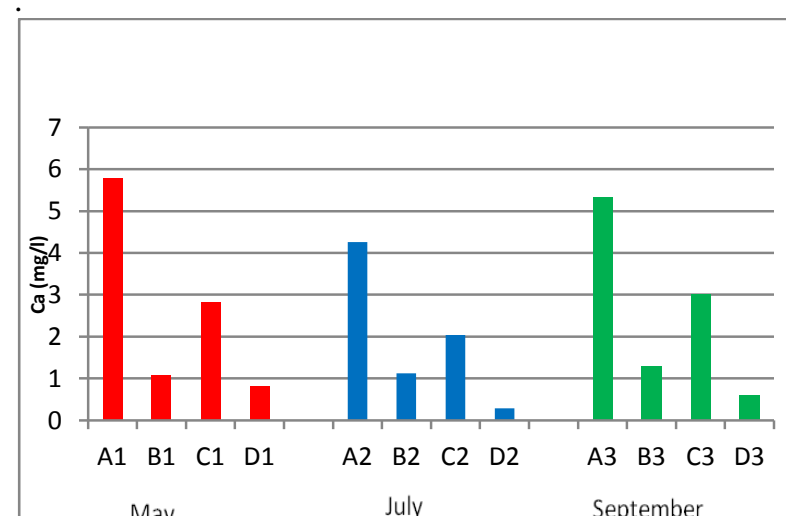

Fig 8: Calcium concentration of rainwater harvested from different roofing materials

$\mathrm{A}=$ Asbestos, $\mathrm{B}=$ Aluminum, $\mathrm{C}=$ Zinc, $\mathrm{D}=$ Control

The value of sodium for all water samples analyzed from the roofing sheets ranged from 3.15-3.41 mg/l, $3.04-3.90 \mathrm{mg} / \mathrm{l}, 3.94-5.02 \mathrm{mg} / \mathrm{l}$ and $2.79-3.01 \mathrm{mg} / \mathrm{l}$ for asbestos roof, aluminum roof, zinc roof and control

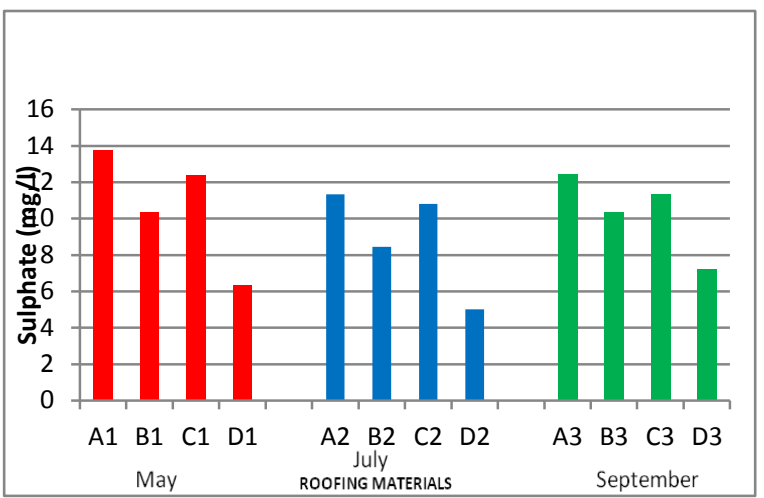

Fig 7: Sulphate concentration of rainwater harvested from different roofing materials $\mathrm{A}=$ Asbestos, $\mathrm{B}=$ Aluminum, $\mathrm{C}=$ Zinc, $\mathrm{D}=$ Control

control samples respectively. Calcium and Magnesium in water gives rise to hardness of water. It was observed from Fig. 7 and Fig. 8 that water samples collected from asbestos roofing sheet gave the highest calcium and magnesium concentrations irrespective of the period of collection. This could be traceable to the level of magnesium and calcium carbonate content that can be leached from the roofing material

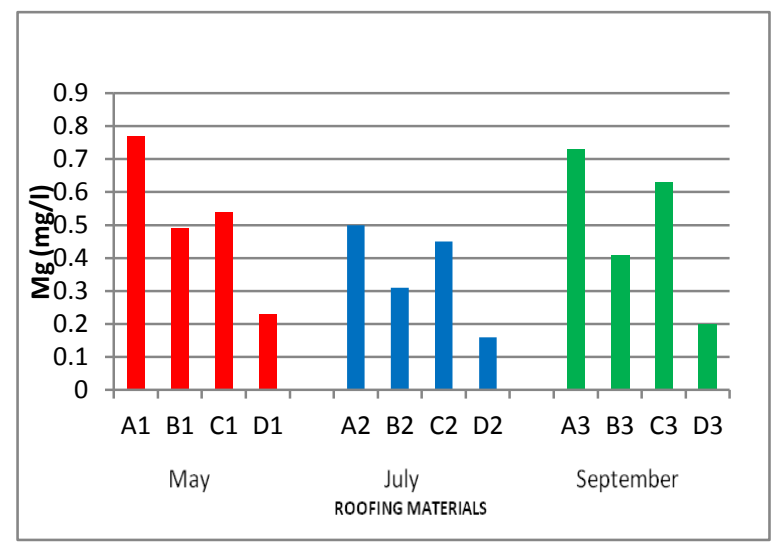

Fig 9: Magnesium concentration of rainwater harvested from different roofing materials

$\mathrm{A}=$ Asbestos, $\mathrm{B}=$ Aluminum, $\mathrm{C}=$ Zinc, $\mathrm{D}=$ Control

respectively. Water sample from zinc roof had the highest value of sodium (Figure 10). 


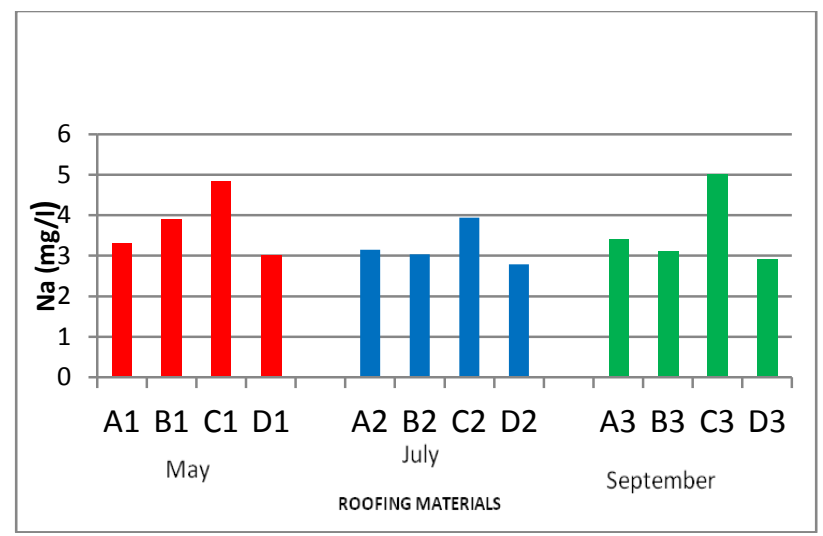

Fig 10: Sodium concentration of rainwater harvested from different roofing materials $\mathrm{A}=$ Asbestos, $\mathrm{B}=$ Aluminum, $\mathrm{C}=$ Zinc, $\mathrm{D}=$ Control

It was observed from Figure 11 that samples from zinc roofing sheet had the highest value of zinc as compared to other roofing sheets and the control. The values of zinc concentration from all the samples ranged from 1.02-1.23 mg/l, 0.11-1.04 mg/l, 3.39$4.08 \mathrm{mg} / \mathrm{l}$ and $0.01-0.05 \mathrm{mg} / \mathrm{l}$ for asbestos, aluminum, zinc roofs and control water samples respectively. This reflects a general contamination of the runoff from the zinc roofing sheet by the metal, which could be as a result of corrosion. Lead was not detected in any of the water samples analyzed. This may be due to the fact there are no industries and heavy traffic in the study area in which the samples were collected. According to Eletta and Oyeyipo, 2008 lead was also not detected from most of the rainwater samples harvested from roof runoff. However, all analyzed samples for metals fell within the WHO allowable limits for metals in drinking water except for Iron which had a value of $0.37 \mathrm{mg} / \mathrm{l}$ and $0.62 \mathrm{mg} / \mathrm{l}$ in water sample collected from zinc roofing sheet (Table 1).

Conclusion: Rooftop runoff quality is dependent on both the roof type and the environmental conditions (not only the local climate but also the atmosphere pollution). From the results presented in this research, it is observed that though quality of water harvested from the selected roofing materials at different rainfall periods fall within the WHO standard limit, some level of contamination was prominent. The water samples from asbestos roofing sheet relatively had the highest level of contamination, followed by zinc roofing sheet and then aluminum roofing sheet had the least contamination. The result also indicated that that the concentrations of the physicochemical parameters as well as the metals from the roofing sheets were considerably higher than those of control samples. This could mean that the impinging of rain drop on the roof gradually erodes the material used in

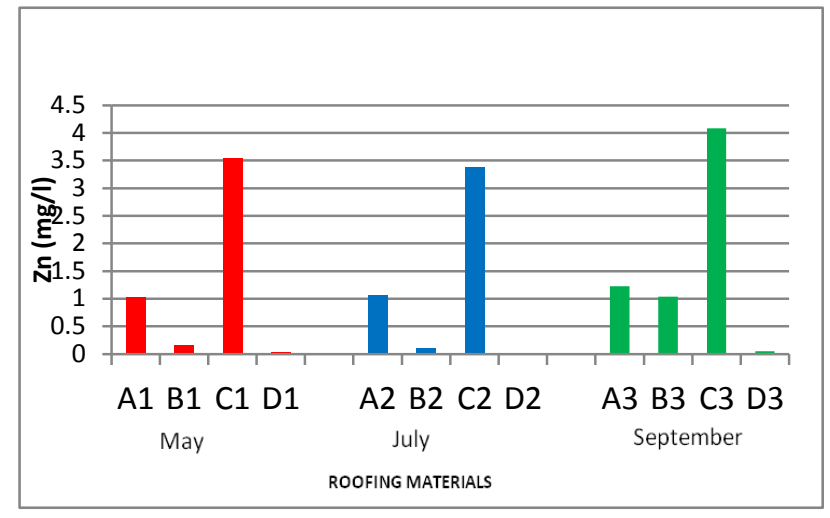

Fig 11: Zinc concentration of rainwater harvested from Different roofing materials $\mathrm{A}=$ Asbestos, $\mathrm{B}=$ Aluminum, $\mathrm{C}=$ Zinc. $\mathrm{D}=$ Control

the making of the roof. However, the variations in the concentration could be as a result of anthropogenic inputs (deposit pollutants in contact with roofing sheets). Also, geographical location could have affected the level of contamination. Rainwater from aluminum roofing sheet proved to be most suitable. None the less, to ensure rainwater satisfies health requirement for consumption, all rainwater should be given some level of treatment. However, all rainwater samples are quite safe for all other domestic uses such as laundry, bathing, toilet flushing and other cleaning works.

\section{REFERENCES}

APHA, (1998). Standard method for the examination of water and waste water, $20^{\text {th }}$ ed.,

American public health association, Washinton, DC, p1220.

Chang, M; McBroom, W and Beasley, R. (2004). Roofing as a source ofnon-point water pollution.Journal of Environmental management. 73(4): 307-315.

Eletta, O.A and Oyeyipo, J.O. (2008). Rainwater Harvesting:Effect of Age of Roof on Water Quality. International journal of Applied Chemistry. 4(2): 157-162.

Eruola, A.O; Ufoegbune, G.C; Awomeso, J.A; Adeofun, C.O; Idowu, O.A; and Sowunmi, A. (2010).Qualitative and Quantitative Assessment of Rainwater Harvesting from Rooftop

Catchments: Case Study of Oke-Lantoro Community in Abeokuta, Southwest Nigeria. 32: $47-56$

Gould, J. and Nissen-peterson, E. (1999).Rainwater 
catchmentsystems for domestic rain: design construction and implementation intermediate Technology Publication London. p. 335 .

Mendez, B.C; Brigit, R.A; Kerry K; Micheal, E.B and Mary, K.(2010). Effect of Roof Material on Water Quality for Rainwater Harvesting Systems. Texas water Development Board Report, p. 2

Olaoye, R.A and Olaniyan, O.S (2012). Quality of rain water from different roof materials: International journal of Engineering and Technology 2(8): 1413-1414.

Quek, U. and Forster, J. (1993).Trace metalsin roof runoff.Water Air and Soil Poll 68(34):373-89.
Ragab, R; Bromey, J; Roser, P; Cooper, J.D and Cash, H.C. (2003). "Experimental study of water fluxes in a residential area: rainfall, roof runoff and evaporation, the effect of slope and aspect" Journal of Hydrological Process, 17(12): 24092422.

Simmons, G; Hope, V; Lewis, G; Whitmore, J. and Gao, W. (2001). Contamination of potable roofcollected rainwater in Auckland, New Zealand. Water Res.35(6):1518-1524.

Vikaskumar, G.S; Hugh, D; Phillip, M.G; Peter, C; Timothy, K.R and Tony, R.(2007).

Comparison of water quality parameters from diverse catchments during dry periods and

$$
\text { following rain events.Water Research }
$$
41(16): 3655-3666.

Yaziz, M; Gunting, H; Sapari, N; and Ghazali, A. (1989). Variations in Rainwater Quality fromRoof Catchments, Water Resource 23(6): 761-765. 